\title{
Adjuvant Therapy of Pancreatic Cancer Using Monoclonal Antibodies and Immune Response Modifiers
}

\author{
Helmut Friess, * Michael Gassmann, and Markus W. Büchler \\ Department of Visceral and Transplantation Surgery, University of Bern, Inselspital, Bern, Switzerland
}

\begin{abstract}
Summary
Pancreatic cancer is a devastating disease with poor survival. At present, no effective adjuvant or palliative therapies are available. Unresponsiveness to chemotherapy, radiotherapy, and antihormonal treatment is one of the reasons that pancreatic cancer patients have an overall median survival time of 4-6 mo. This article summarizes clinical trials on immunotherapy of pancreatic cancer using the murine monoclonal antibodies (MAbs) 17-1A and BW 494. In addition, the use of MAb treatment in combination with immune response modifiers is discussed. In four clinical trials, MAb 17-1A was given by iv infusion to 100 patients with pancreatic cancer. In 30 of these patients, antibody treatment was accompanied by $\gamma$-interferon, also given intravenously. Complete response, partial response, and stable disease were reported in 1, 5, and 23 patients, respectively. Passive immunotherapy using the MAb BW 494 was carried out in 148 pancreatic cancer patients in two phase I and two phase II trials. In 1 out of 75 patients a partial response and in 25 out of 74 patients stable disease were reported. However, in a controlled, randomized trial enrolling 61 patients following Whipple resection, comparable survival times in patients with and without MAb BW 494 treatment led to the termination of further clinical trials with this antibody. New clinical studies using humanized MAbs in combination with immune response modifiers should be initiated to further evaluate immunotherapy as a treatment option in pancreatic cancer.
\end{abstract}

Key Words: Pancreatic cancer; treatment; immunotherapy; growth factors; monoclonal antibody.

\section{Introduction}

In the age of modern diagnostic procedures and highly developed conservative and surgical therapeutic strategies in oncology, pancreatic cancer is still a devastating disease with poor prognosis $(1,2)$. In the past decades, the incidence of cancer of the pancreas has apparently been increasing, and it is

Received and Accepted September 15, 1996

*Author to whom all correspondence and reprint requests should be addressed: Department of Visceral and Transplantation Surgery, University of Bern, Inselspital, CH-3010 Bern, Switzerland. now the fourth leading cause of cancer death in Western industrialized countries $(1,2)$. The therapeutic possibilities and perspectives in this malignancy have not changed fundamentally over the past few years. Although chemotherapy, radiotherapy, and antihormonal therapy have improved the prognosis of a variety of human malignancies, cancer of the pancreas seems not to respond to any of these treatment strategies (3-11). Only early detection of cancer of the pancreas followed by resection of the pancreatic tumor offers the possibility to improve survival or cure patients with pancreatic cancer $(2,12)$. However, the curative resectability rate in 
pancreatic cancer is low and does not exceed 15-35\% $(2,12)$. This is because the late and unspecific symptoms that lead to the diagnosis of the malignancy in most patients occur when the tumor has already spread into lymph nodes or distant metastases are present $(2,12)$. Therefore, at present, the overall 5-yr survival rate in pancreatic cancer is $<1 \%$, and only $15-20 \%$ of the patients with curative tumor resection live longer than $5 \mathrm{yr}$ (2).

The reasons for the aggressiveness and the extremely malignant potential of pancreatic cancer are not known. It has been reported that pancreatic cancer cells overexpress the epidermal growth factor (EGF) receptor and its ligands EGF and transforming growth factor alpha (TGF- $\alpha)(13,14)$. The concomitant presence of the EGF receptor with either EGF and/or TGF- $\alpha$ or amphiregulin in pancreatic cancer cells is associated with tumor aggressiveness and shorter patient survival periods $(14,15)$. In addition, overexpression of aFGF, bFGF, TGF- $\beta$ s, TGF- $\beta$ receptors, c-erbB-2, c-erbB-3, c-met, HGF, as well as $\mathrm{K}$-ras and 53 mutations are also commonly found in pancreatic cancer (16-25). These findings indicate that alterations in the expression of growth factors, growth factor receptors, and K-ras and p53 mutations may provide an important pathophysiological mechanism in pancreatic cancer and seem to give pancreatic cancer cells a fundamental growth advantage.

The dilemma for clinicians dealing with patients with pancreatic cancer is the lack of any effective palliative or curative treatment possibilities. Therefore, new and unconventional treatment strategies must be developed, and their effectiveness has to be investigated in clinical trials.

The present article deals with the results of clinical trials using the monoclonal antibodies (MAbs) 17-1A (MAb 17-1A), BW 494 (MAb BW 494), and immune response modifiers in patients with pancreatic cancer. The results of these studies have been published in detail elsewhere $(26-36)$.

\section{Immunotherapy of Pancreatic Cancer with the MAb 17-1A}

\section{Rationale for the Use of the MAb 17-1A in the Treatment of Pancreatic Cancer}

The MAb 17-1 A is a murine IgG2a isotype, which was developed by immunizing mice with the supernatant of colorectal carcinoma cell line SW1038(37-
39). This MAb is immunoreactive with a variety of gastrointestinal malignancies, and was originally used in clinical trials enrolling patients with colorectal, pancreatic, and gastric cancers (40). Following binding to a $37-\mathrm{kDa}$ glycoprotein, the MAb 17-1A initiates an antibody-dependent cellular cytotoxicity (ADCC) in the presence of monocytes or macrophages (41). This means that binding of the antibody to the cancer cells leads to the activation of immune cells, which will destroy antibody-labeled cells. In nude mice, administration of MAb 17-1A inhibited the growth of human tumor and caused an increase in activated macrophages in the tumor mass (41).

\section{Clinical Trials with the MAb 17-1A}

In 1984, the first clinical trials with MAb 17-1A were started in patients with advanced pancreatic cancer. In total, 43 patients were enrolled in two phase II studies $(26,27)$. The patients were treated with a total dosage of $400-500 \mathrm{mg}$ MAb 17-1A admixed with approx $10^{9}$ autologous mononuclear cells, which were isolated by standard leukopheresis technique. Partial response was reported in four patients $(10 \%)$. Nine patients $(21 \%)$ had stable disease, and in $69 \%$ of the patients, tumor progression was observed. No severe side effects of MAb 17-1A therapy were reported in either study.

Thirteen of 16 patients ( $81 \%$ ) analyzed for the development of human antimouse antibodies showed a significant human antimouse antibody (HAMA) response (27). The formation of anti-idiotypic human antimouse antibodies may lead to the production of human antibodies that bind again to the cancer cells, and may cause direct or indirect tumor cell destruction.

\section{Combination of MAb 17-1A Treatment with Immune Response Modifiers}

\section{Clinical Trials with the MAb 17-1A \\ in Combination with Gamma-Interferon ( $\gamma$-Interferon)}

The promising findings of these two phase II trials with MAb 17-1A in pancreatic cancer patients stimulated the initiation of further clinical studies. To enhance the efficacy of MAb 17-1A treatment, Tempero et al. started a phase II trial in which MAb 17-1A, peripheral mononuclear cells, and $\gamma$-interferon were administered simultaneously (28). $\gamma$-Interferon is a potent activator of macrophages and 
monocytes. These act as effecter cells in the ADCC reaction initiated by the binding of the MAb 17-1A to the cancer cells. In addition, $\gamma$-interferon increases the number of $\mathrm{Fc}$ receptors on macrophages and monocytes, and thereby may lead to an enhanced lytic rate of the tumor cells. Out of 30 patients treated in this manner, 25 were evaluable for response analysis. There was one patient with complete response ( $4 \mathrm{mo}$ ), and nine patients (36\%) experienced stable disease (duration between 4 and 48 mo). Tumor progression was observed in 15 patients $(60 \%)$. MAb 17-1A treatment in combination with $\gamma$-interferon was tolerated well in all patients except one. This patient experienced an anaphylactic reaction owing to pre-existing human antimouse antibodies. In the other patients, no side effects of the treatment occurred.

\section{Combination of the MAb 17-1A \\ with Interleukin-2}

Combination of MAb 17-1A with interleukin-2 in in vitro experiments did not enhance the lytic activity of MAb 17-1A treatment alone (29). Interleukin-2 is an inducer of lymphokine-activated killer cells, which are potent cytolytic cells capable of lysing natural killer cell-resistant tumor cells. However, the combination of interleukin-2 and MAb 17-1A failed to augment the lytic activity in six human pancreatic cancer cell lines. Therefore, no clinical studies have been started to analyze the combination of MAb 17-1A and interleukin-2 in patients with pancreatic cancer.

\section{Long-Term Treatment \\ of Advanced Pancreatic Cancer \\ with the MAb 17-1A}

The first clinical studies with the IgG2a murine MAb 17-1A employed single infusions of the MAbs or treatment schedules of $<10 \mathrm{~d}$. These treatment schedules were used because murine MAb 17-1A treatment induces human antimouse antibodies, which might cause hypersensitivity reactions. However, it is not known if repeated dosing schedules may enhance the efficacy of unconjugated MAb 17-1A therapy in patients with pancreatic cancer. In 1993, Weiner and coworkers published a phase II multicenter evaluation of prolonged MAb 17-1A treatment in 28 patients with unresectable pancreatic cancer (30). Sixteen patients received a total dosage of $12 \mathrm{~g} \mathrm{MAb}$ 17-1A. The antibodies were administered in single dosages of $500 \mathrm{mg}$ three times weekly for $8 \mathrm{wk}$. Five patients showed hypersensitivity reactions within $3 \mathrm{wk}$ of the beginning of antibody treatment. Six additional patients were withdrawn from the study because of rapid tumor progression and one was withdrawn because of violation of the study protocol. Response evaluation was possible in 22 patients. One patient had partial response for more than $3 \mathrm{yr}$, 5 patients had brief periods of stable disease, and 16 patients $(73 \%)$ had progressive tumor disease. The mean survival of all patients was $11.7 \mathrm{wk}$, and the mean progression free survival was $7 \mathrm{wk}$. Human antimouse antibodies were not identified in any patient following MAb 17-1A therapy. This phenomenon may have been owing to complexing of HAMA with circulating MAb 17-1 A rather than to the lack of HAMA production. The authors concluded from their results that long-term MAb 17-1A therapy in patients with advanced pancreatic cancer was well tolerated, but was not effective in prolonging survival.

\section{Immunotherapy of Pancreatic Cancer with the MAb BW 494}

\section{Rationale for the Use of the MAb BW 494 in the Treatment of Pancreatic Cancer}

The MAb BW 494 was developed and characterized by Bosslet and coworkers in 1986 (42). It is a murine immunoglobulin (IgG1 isotype) that recognizes a membrane and cytoplasmic $200-\mathrm{kDa}$ carbohydrate antigen that is expressed in pancreatic cancer cells. It was derived from $\mathrm{Balb} / \mathrm{c}$ mice that were immunized with the DE-TA colon carcinoma cell line (42).

The first clinical trials with the MAb BW 494 against pancreatic carcinoma were based on the following characteristics:

1. The antibody shows strong binding capacity to well and moderately differentiated human pancreatic cancer cells in vitro and in vivo. Immunohistochemical analysis revealed a binding sensitivity to more than $90 \%$ of pancreatic adenocarcinomas (42-44);

2. The antibody mediates ADCC with human mononuclear cells against ${ }^{51} \mathrm{CR}$-labeled pancreatic cancer target cells (42);

3. In vitro, the antibody inhibits specific functions of pancreatic cancer cells, such as endocytosis, superoxide anion generation, and the release of lysosomal enzymes $(45,46)$; and 
Table 1

Clinical Trials with the MAb BW 494 in Patients with Pancreatic Cancer ${ }^{a}$

\begin{tabular}{lll}
\hline Phase I (high dose) & 13 patients & Ulm, Hannover \\
Phase I (pilot study) & 39 patients & Ulm, Giessen, Hamburg \\
Phase II (uncontrolled) & 35 patients & Ulm, Giessen, Nijmegen \\
$\begin{array}{l}\text { Phase II (controlled, } \\
\text { randomized) }\end{array}$ & 61 patients & Ulm, Nürnberg, Giessen, \\
& & Düsseldorf, Nijmegen \\
\hline
\end{tabular}

\begin{abstract}
${ }^{a}$ Participating centers: Department of Surgery, University of Ulm, Germany; Department of Surgery, University of Giessen, Germany; Department of Surgery, Klinikum Nürnberg, Germany; Department of Internal Medicine, University Hospital, Hamburg, Germany; Department of Internal Medicine, University of Hannover, Germany; Department of Hematology, Oncology and Clinical Immunology, Heinrich Heine University Düsseldorf, Germany; Department of Internal Medicine, Division of Oncology, University of Nijmegen, The Netherlands.
\end{abstract}

4. Single injection of ${ }^{131}$ I-labeled antibody leads to growth suppression of human pancreatic tumors transplanted into nude mice (47).

\section{Clinical Trials with the MAb BW 494}

From 1985-1989, four clinical trials using the MAb BW 494 in 148 patients with pancreatic cancer were carried out (Table 1) (31-36). There were two phase I studies (1985-1988), one uncontrolled phase II study in patients with unresectable pancreatic cancer (1987-1988) and one controlled, randomized phase II trial in patients with resectable tumors (Whipple resection) and no distant metastases (19871989). All four studies were multicentric and carried out at the Universities of Ulm, Giessen, Nürnberg, Hamburg, Hannover and Düsseldorf, Germany, as well as Nijmegen in the Netherlands.

\section{MAb BW 494: Phase I Study (High Dose)}

Thirteen patients with distant metastases (M1, according to UICC, 1987 [48]) were included in this trial to determine the pharmacokinetics and doserelated side effects of iv MAb BW 494 application (32). In every two patients, a single iv infusion of $100,200,400,600,800$, and $1000 \mathrm{mg}$ MAb BW 494 was applied (up to $250 \mathrm{mg} / \mathrm{h}$ ). Following the end of the MAb infusion, a total of 16 blood samples were taken within $10 \mathrm{~d}$, and the concentration of the murine IgGl was measured. The calculated initial half-life of the MAb BW 494 was $12 \mathrm{~min}$, and the terminal half-life was $47.8 \mathrm{~h}$, respectively $(31,32,34)$.

Antibody dosages between 100 and $400 \mathrm{mg}$ were well tolerated without any side effects. In starting higher dosages (600-1000 mg), six of eight patients showed side effects, such as diarrhea, vomiting, and abdominal discomfort (32). All side effects could be controlled without further complications by stopping the infusion and symptomatic drug treatment.

\section{MAb BW 494: Phase I Study (Pilot Study)}

A total of 39 patients with advanced pancreatic cancer (T3 or N1 or M1, according to UICC, 1987 [48]) were included in this trial $(31,32,34,35)$. Further inclusion criteria were a Karnofsky performance status above $30 \%$ and a predicted survival period longer than $3 \mathrm{mo}$. The study design also included laparotomy and histological proof of pancreatic adenocarcinoma as well as the immunohistochemical binding analysis of MAb BW 494 in tumor samples. Once written informed consent was obtained from the patients, immunotherapy was usually started between the second and third postoperative week. In keeping with the design of a phase I study, three different application protocols were used (Table 2). The first patients were treated on five successive days, beginning with an initial dosage of $20 \mathrm{mg}$ MAb BW 494 and increasing by $20 \mathrm{mg}$ daily up to a total dosage of $300 \mathrm{mg}$. The second group of patients received an initial dosage of $50 \mathrm{mg} \mathrm{MAb} \mathrm{BW} \mathrm{494,} \mathrm{followed} \mathrm{by}$ constant dosages of $30 \mathrm{mg}$ in 3-d intervals up to a total dosage of $150-230 \mathrm{mg}$ over a total treatment period of $3 \mathrm{wk}$. Owing to anaphylactic side effects in this protocol, the mode of application was shortened in all further trials to a 10-d treatment protocol. The patients were treated with an initial dosage of $100 \mathrm{mg}$ MAb BW 494 and subsequent infusions of a constant dosage of $30 \mathrm{mg}$ in the following $9 \mathrm{~d}$. The antibody was always diluted in $100 \mathrm{~mL}$ of $0.9 \%$ sodium chloride solution and administered via a peripheral vein 
Table 2

Intravenous Application Protocols

of the MAb BW 494 in Patients with Advanced Pancreatic Cancer

\begin{tabular}{lcl}
\hline $\begin{array}{c}\text { Duration of MAb } \\
\text { application }\end{array}$ & Total dosage & \multicolumn{1}{c}{ Single MAb infusions } \\
\hline $1 \mathrm{wk}$ & $300 \mathrm{mg}$ & $20,40,60,80,100 \mathrm{mg}$ \\
$3 \mathrm{wk}$ & $230 \mathrm{mg}$ & $50,30,30,30,30,30,30 \mathrm{mg}$ \\
$2 \mathrm{wk}$ & $370 \mathrm{mg}$ & $100,30,30,30,30,30,30,30,30,30 \mathrm{mg}$ \\
\hline
\end{tabular}

over a time period of $30-60 \mathrm{~min}$. During the antibody infusions, the patients were carefully monitored for general and cardiovascular status to control possible allergic reactions. The patients were followed up every $4 \mathrm{wk}$ in the outpatient clinic. They were checked for general clinical status, Karnofsky performance status, tumor progression via ultrasonography and/or contrast-enhanced computed axial tomography scan, and for the serum tumor markers CEA and CA 19-9.

\section{RESULTS}

Immunohistochemical analysis was carried out on a total of 14 tumor specimens. All well- and moderately differentiated tumors exhibited medium to intense immunostaining. However, only $50 \%$ of the undifferentiated pancreatic carcinomas showed immunoreactivity with the MAb BW 494.

There were no side effects to immunotherapy in the majority of the patients. Two patients developed diffuse muscular aches in the lower extremities and in the lumbar region 14 and $20 \mathrm{~d}$ after the first infusion of the MAb BW 494. These symptoms subsided after $48 \mathrm{~h}$ without specific therapy. Two patients experienced anaphylactic reactions during the fifth antibody application on $\mathrm{d} 12$ and during the ninth antibody application on $\mathrm{d} 19$ with severe back pain, tachycardia, and hypotension. Those reactions were immediately controlled without further complications by ceasing the infusion of antibody and administering analgesics, steroids, and epinephrine. Subsequent serum analysis indicated highly positive HAMA titers at the time of the infusion, which may account for the anaphylactic reactions.

Similar anaphylactic reactions were observed in one patient, when a second antibody infusion was given 3 mo after the primary antibody application. Serum analysis also indicated high serum levels of HAMA in this patient. Seventeen of $18(94 \%)$ patients showed HAMA production following repeated application of MAb BW 494. One-third of these HAMA were anti-idiotypic.

One of the patients in this trial had a partial remission $(3 \%)$, and $23 \%(9 / 39)$ showed stable disease for at least 3 mo following antibody treatment. Seventy-four percent (29/39) of the patients had continuous tumor progression. The median survival was 5 mo in all patients, $3 \mathrm{mo}$ in patients with progressive disease, and $13 \mathrm{mo}$ in patients with partial remission or stable disease.

\section{MAb BW 494: Phase II Study (Uncontrolled)}

Between 1987 and 1988, a phase II trial with pancreatic cancer patients who had nonresectable tumors and no evidence of distant metastases was carried out (32). Thirty-five patients from Ulm, Giessen, and Nijmegen were included in this uncontrolled study. A total dosage of $370 \mathrm{mg}$ of MAb BW 494 was given intravenously within $10 \mathrm{~d}$ according to the third application regimen in the pilot study (Table 2). No side effects of the antibody treatment were registered. The median survival period for all patients was $6.5 \mathrm{mo}$. Forty-seven percent of the patients showed stable disease for at least $3 \mathrm{mo}$ (WHO classification), and $53 \%$ of the patients exhibited tumor progression. Partial or complete tumor remission was not observed in any patient.

\section{MAb BW 494: Phase II Study \\ (Controlled, Randomized)}

The encouraging findings of the pilot and the uncontrolled phase II trial with the MAb BW 494 justified the initiation of a controlled, randomized study in patients with resectable pancreatic cancer (33). The hypothesis for this study was that if passive immunotherapy with the MAb BW 494 was to have any effect, it would be in patients with pancreatic cancer having the smallest possible tumor lesion.

Sixty-five patients with suspected pancreatic cancer were recruited prospectively for this study. Inclu- 
Table 3

Controlled, Randomized Phase II Trial in 61 Patients with Pancreatic Cancer and Whipple Resection ${ }^{a}$

\begin{tabular}{lcc}
\hline & $\begin{array}{c}\text { MAb BW 494 } \\
\text { treatment }\end{array}$ & $\begin{array}{c}\text { Control } \\
\text { group }\end{array}$ \\
\hline No. of patients & 29 & 32 \\
Median age & $59 \mathrm{yr}$ & $59 \mathrm{yr}$ \\
Min-max & $29-74 \mathrm{yr}$ & $30-75 \mathrm{yr}$ \\
Sex & & \\
$\quad$ Female & 14 & 16 \\
$\quad$ Male & 15 & 16 \\
\hline
\end{tabular}

${ }^{a}$ Two weeks after surgery, the patients were randomized into the MAb BW 494 treatment group or into the control group (no MAb BW 494 treatment).

sion criteria were tumor resectability, no distant metastases, a histologic grade 1 or 2 (according to UICC, 1987 [48]), a Karnofsky performance status $>70 \%$, and written informed consent. Two weeks after the Whipple resection, the patients were randomized to receive either MAb BW 494 treatment or no additional therapy (control group). Four patients were excluded because of distal common bile duct cancer. Sixty-one patients (Table 3) with histologically confirmed pancreatic adenocarcinoma were available for final evaluation (29 patients with MAb BW 494 treatment; 32 patients in the control group).

Patients in the treatment group received iv antibody infusions over $10 \mathrm{~d}$, starting with a dosage of $100 \mathrm{mg}$ of MAb BW 494 and continuing with 9 infusions of $30 \mathrm{mg}$ on the following $9 \mathrm{~d}$. A monthly follow-up consisted of physical examination, measurement of the serum tumor markers CEA and CA 19-9, and contrast-enhanced computed axial tomography scan and/or ultrasonography of the upper abdomen.

\section{RESULTS}

Both the MAb BW 494 treatment group and the control group were balanced with respect to age, gender, tumor stage, and tumor grade (Tables 3 and 4). Sixty-two percent $(16 / 29)$ of the patients in the treatment group and $72 \%(23 / 32)$ of the patients in the control group had lymph node metastases (Table 4).

Six patients suffered from side effects of the MAb BW 494 treatment. Four patients had nausea and vomiting (WHO, Grade 2), one had severe abdominal pain (WHO, Grade 3), and one patient had fever and chills $1 \mathrm{~h}$ after the final application of the MAb. All side effects were responsive to drug treatment,
Table 4

Controlled, randomized Phase II TrialTNM Classification and Tumor Grading (UICC, 1987) ${ }^{a}$

\begin{tabular}{|c|c|c|}
\hline & $\begin{array}{c}\text { MAb BW } 494 \\
\text { treatment }\end{array}$ & $\begin{array}{l}\text { Control } \\
\text { group }\end{array}$ \\
\hline & 29 patients & 32 patients \\
\hline $\mathrm{Tx}$ & 2 & 3 \\
\hline $\mathrm{T} 1$ & 7 & 4 \\
\hline $\mathrm{T} 2$ & 17 & 21 \\
\hline $\mathrm{T} 3$ & 3 & 4 \\
\hline $\mathrm{Nx}$ & 3 & 0 \\
\hline N0 & 10 & 9 \\
\hline N1 & 16 & 23 \\
\hline M0 & 29 & 32 \\
\hline G1 & 7 & 11 \\
\hline G2 & 22 & 19 \\
\hline G3 & 0 & 2 \\
\hline Median survival & $428 \mathrm{~d}$ & $386 \mathrm{~d}$ \\
\hline Range & $248-510 \mathrm{~d}$ & $296-509 \mathrm{~d}$ \\
\hline
\end{tabular}

and MAb treatment did not have to be interrupted in any patient. The postoperative survival data were computed by the method of Kaplan-Meier. The median survival period in patients with MAb BW 494 treatment was $428 \mathrm{~d}$ (range: $248-510 \mathrm{~d}$ ), and the median in the control group was $386 \mathrm{~d}$ (range: $296-$ $509 \mathrm{~d}$ ). This difference was statistically not significant. Stratification of the patients with respect to age (older than $60 \mathrm{yr}$ ), sex, and staging (N0 vs N1) did not reveal any improvement of the median survival from MAb BW 494 treatment in these subgroups. The negative results of this study led to the termination of further clinical trials in pancreatic cancer using the MAb BW 494.

\section{The Future Perspectives \\ of MAb Treatment in Pancreatic Cancer}

Between 1984 and 1993, eight clinical trials were performed using the murine MAbs 17-1 A or BW 494 for passive immunotherapy in pancreatic cancer $(26-$ 36). In the case of MAb 17-1A, these studies consisted of four phase II studies. In the case of MAb BW 494 , it consisted of a phase I trial to evaluate side effects of a single antibody dosage (up to $1000 \mathrm{mg}$ of 
antibody protein), a pilot study (phase I) in patients with advanced tumor stages, an uncontrolled phase II study in patients with unresectable pancreatic tumors, and a controlled, randomized phase II study in patients with resectable pancreatic tumors.

Treatment with the murine MAb 17-1A and MAb BW 494 was well tolerated, and did not cause severe side effects in the majority of patients. In advanced tumor stages of pancreatic cancer, antibody treatment (MAb 17-1A or MAb BW 494) seemed to benefit one-third of the patients. However, in a controlled, randomized trial using MAb BW 494 in patients following Whipple resection, no improvement in the survival periods was found (33).

The MAb 17-1A is a murine monoclonal IgG2 antibody, and the MAb BW 494 is a murine monoclonal IgG1 antibody. They are directed against a cytoplasmic and membrane antigen in pancreatic cancer cells (42). Binding of the MAb BW 494 to tumor cells initiates the activation of macrophages or of lymphocytes with killer cell activity mediating direct cytotoxic effects on the cancer cells $(42,45,46)$. Similar effects have been shown for MAb 17-1 A and IgG3 isotype MAbs, which have been used in uncontrolled clinical trials in pancreatic cancer, other gastrointestinal cancers, and malignant melanomas (49-52).

The application of the murine MAb 17-1A and MAb BW 494 induced HAMAs in 13 of 16 patients $(81 \%)$ and in 17 of 18 patients $(94 \%)$, respectively. One third of the HAMAs were anti-idiotypic (53). Although these HAMAs prohibited further antibody applications, this idiotypic-anti-idiotypic antibody response suggests a self-vaccination against the tumor in which the anti-idiotypic antibodies bear the internal image of the tumor-associated antigen (5456). Antibodies against this tumor epitope produced by patients after MAb therapy are tumor-specific human antibodies that may induce further tumor destruction (56-58).

The reasons for the failure of MAb BW 494 treatment in patients with resectable pancreatic cancer (Whipple resection) are not readily evident. There is the possibility that the dosage used in this study was too low to saturate the target epitopes adequately (59). The total MAb BW 494 dosage of $370 \mathrm{mg}$ in this randomized trial was chosen mainly for safety reasons. In other clinical trials using MAbs in the treatment of gastrointestinal tumors, the dosages used were higher than the total dosage of $370 \mathrm{mg}$ used in both the uncontrolled and controlled, randomized phase II trials. With regard to the MAb BW 494, it has been demonstrated that after $3 \mathrm{~d}$ of immunotherapy, insufficient binding of the MAb in several pancreatic cancer tumor areas was detectable despite good vascularization (59). Therefore, therapeutic dosages for humans might have to be higher than those used in the patients following Whipple resection.

Treatment of pancreatic cancer using MAbs is a challenging task for the future. New and more potent MAbs need to be developed. This includes the production of chimeric and humanized MAbs, which may make the application of higher dosages tolerable and clinically feasible $(59,60)$. In this sense, the effects induced by human antibodies might be greater than those elicited by murine antibodies. Furthermore, the MAb treatment might be prolonged for months or years, which could improve the effectiveness of this treatment concept dramatically. A further improvement of immunotherapy seems to be the use of MAbs in conjunction with immune response modifiers, such as interleukin-2, colony-stimulating factors, or cytotoxic substances coupled to antibodies (61-64). The combination of MAb BW 494 with granulocyte-macrophage colony-stimulating factor (GM-CSF) has been shown to enhance the in vitro ADCC reaction threefold compared to MAb treatment alone (65). Therefore, further clinical studies are necessary to investigate the efficiency of new MAbs and MAb treatment in combination with immunomodulators in patients with pancreatic cancer.

A study in patients undergoing curative surgery for Dukes' $\mathrm{C}$ stages of colorectal cancer reported in 1994 that adjuvant treatment with the MAb 17-1A significantly reduced the overall death rate by $30 \%$ and the recurrence rate by $27 \%(66)$. These encouraging data should stimulate further clinical trials of immunotherapy in pancreatic cancer as well.

\section{Acknowledgment}

The authors thank Al Stewart for his assistance in preparing this manuscript.

\section{References}

1 Silverberg E, Lubera JA. Cancer statistics, 1989. Ca Can J Clin 1989; 39: 3-20.

2 Gudjonsson B. Cancer of the pancreas: 50 years of surgery. Cancer 1987; 60: 2284-2303. 
3 Kelsen D, Hudis C, Niedzwiecki D, Dougherty J, Casper E, Botet J, Vinciguerra V, Rosenbluth R. A phase III comparison trial of streptozotocin, mitomycin, and 5-fluorouracil with cisplatin, cytosine arabinoside, and caffeine in patients with advanced pancreatic carcinoma. Cancer 1991; 68: 965-969.

4 Topham C, Glees J, Rawson NS, Woods EM, Coombes RC. Randomized trial of epirubicin alone versus 5-fluorouracil, epirubicin and mitomycin $\mathrm{C}$ in locally advanced and metastatic carcinoma of the pancreas. Br J Cancer 1991; 64: $179-181$.

5 Tennvall J, Ljungberg O, Ahren B, Gustavsson A, Nillson LO. Radiotherapy for unresectable endocrine pancreatic carcinomas. Eur J Surg Oncol 1992; 18: 73-76.

6 Komaki R, Wadler S, Peters T, Byhardt RW, Order S, Gallagher MJ, Herskovic A, Pederson J. High-dose local irradiation plus prophylactic hepatic irradiation and chemotherapy for inoperable adenocarcinoma of the pancreas. A preliminary report of a multi-institutional trial (Radiation Therapy Oncology Group Protocol 8801). Cancer 1992; 69: 2807-2812.

7 Schifeling DJ, Konski AA, Howard JM, Dobelbower RR Jr, Merrick HW 3rd, Skeel RT. Radiation therapy and 5-fluorouracil modulated by leucovorin for adenocarcinoma of the pancreas: a phase I study. Int J Pancreatol 1992; 12: 239-243.

8 Friess H, Büchler M, Krüger M, Beger HG. Treatment of duct carcinoma of the pancreas with the LH-RH analogue buserelin. Pancreas 1992; 7: 516-521.

9 Friess H, Büchler M, Beglinger Ch, Weber A, Kunz J, Fritsch K, Beger HG. Low dose octreotide treatment is not effective in patients with advanced pancreatic cancer. Pancreas 1993; 8: 540-545.

10 Friess H, Büchler MW, Ebert M, Malfertheiner P, Dennler $\mathrm{HJ}$, Beger HG. Treatment of advanced pancreatic cancer with high dose octreotide. Int J Pancreatol 1993; 14: 290,291.

11 Bramhall SR, Neoptolemos JP. Role of adjuvant chemoand radiotherapy in pancreatic cancer. Dig Surg 1994; 11 : 408-413.

12 Watanapa P, Williamson RC. Surgical palliation for pancreatic cancer: developments during the past two decades. Br J Surg 1992; 79: 8-20.

13 Korc M, Chandrasekar B, Yamanaka Y, Friess H, Büchler $\mathrm{M}$, Beger HG. Overexpression of the epidermal growth factor receptor in human pancreatic cancer is associated with concomitant increase in the levels of epidermal growth factor and transforming growth factor alpha. $J$ Clin Invest 1992; 90: 1352-1360.

14 Yamanaka Y, Friess H, Kobrin MS, Büchler M, Beger HG, Korc M. Coexpression of epidermal growth factor receptor and ligands in human pancreatic cancer is associated with enhanced tumor aggressiveness. Anticancer Res 1993; 13: 565-570.

15 Yokoyama M, Ebert M, Funatomi H, Friess H, Büchler MW, Johnson GR, Korc M. Amphiregulin is a potent mitogen in human pancreatic cancer cells: correlation with patients' survival. Int J Oncol 1995; 6: 625-631.

16 Yamanaka Y, Friess H, Büchler MW, Beger HG, Uchida E, Masahiko O, Kobrin MS, Korc M. Overexpression of acidic and basic fibroblast growth factors in human pancreatic cancer correlates with advanced tumor stage. Cancer Res 1993; 53: 5289-5296.

17 Friess H, Yamanaka Y, Büchler MW, Ebert M, Beger HG, Gold LI, Korc M. Enhanced expression of transforming growth factor-beta isoforms in pancreatic cancer correlates with decreased survival. Gastroenterology 1993; 105 : 1846-1856.

18 Friess H, Yamanaka Y, Büchler MW, Beger HG, Kobrin MS, Baldwin RL, Korc M. Enhanced expression of the type II transforming growth factor-beta receptor in human pancreatic cancer cells without alteration of type III receptor expression. Cancer Res 1993; 53: 2704-2707.

19 Yamanaka Y, Friess H, Büchler MW, Kobrin MS, Kunz J, Beger HG, Korc M. Overexpression of HER2/neu oncogene in human pancreatic carcinoma. Hum Pathol 1993; 24: 1127-1134.

20 Korc M, Yokoyama M, Friess H. HER2/neu immunostaining in pancreatic carcinoma. Hum Pathol 1994; 25: 5.

21 Friess H, Yamanaka Y, Korc M, Büchler MW. Overexpression of c-erbB-3 in human pancreatic cancer: correlation with tumor aggressiveness. Digestion 1994; 55: 59,299.

22 Ebert M, Yokoyama M, Friess H, Büchler MW, Korc M. Coexpression of the $c$-met protooncogene and hepatocyte growth factor in human pancreatic cancer. Cancer Res 1994; 54: 5775-5778.

23 Grünewald K, Lyons J, Fröhlich A, Feichtinger H, Weger RA, Schwab G, Janssen JWG, Bartram CR. High frequency of Ki-ras codon 12 mutations in pancreatic adenocarcinomas. Int J Cancer 1989; 43: 1037-1041.

24 Barton CM, Staddon SL, Hughes CM, Hall PA, O'Sullivan C, Kloppel G, Theis B, Russell RCG, Neoptolemos J, Williamson RCN, Lane DP, Lemoine NR. Abnormalities of the p53 tumor suppressor gene in human pancreatic cancer. Br J Cancer 1991; 64: 1076-1082.

25 Casey G, Yamanaka Y, Friess H, Kobrin MS, Lopez ME, Büchler M, Beger HG, Korc M. p53 mutations are common in pancreatic cancer and are absent in chronic pancreatitis. Cancer Lett 1993; 69: 151-160.

26 Tempero MA, Pour PM, Uchida E, Herlyn D, Steplewski Z. Monoclonal antibody $\mathrm{CO} 17-1 \mathrm{~A}$ and leukopheresis in immunotherapy of pancreatic cancer. Hybridoma 1986; 5: 133-138.

27 Sindelar WF, Maher MM, Herlyn D, Sears HF, Steplewski $Z$, Koprowski H. Trial of therapy with monoclonal antibody 17-1 A in pancreatic carcinoma: preliminary results. Hybridoma 1986; 5(Suppl 1): 125-132.

28 Tempero MA, Sivinski CL, Steplewski Z, Harvey E, Klassen L, Kay HD. Phase II trial of gamma interferon and monoclonal antibody 17-1 A in pancreatic cancer: biological and clinical effects. J Clin Oncol 1990; 8: 2019-2026.

29 Tempero MA, Haga Y, Sivinski C, Steplewski Z, Kay HD, Pour P. Immunotherapy with monoclonal antibody (MAB) in pancreatic adenocarcinoma. Int J Pancreatol 1991; 9: 125-134.

30 Weiner LM, Harvey E, Padavic-Shaller K, Willson JK, Walsh C, LaCreta F, Khazaeli MB, Kirkwood JM, Haller DG. Phase II multicenter evaluation of prolonged murine monoclonal antibody 17-1A therapy in pancreatic carcinoma. J Immunother 1993; 13: 110-116. 
31 Büchler M, Kübel R, Malfertheiner P, Friess H, Schulz G, Bosslet K, Beger HG. Immunotherapy of advanced pancreatic carcinoma with the monoclonal antibody BW 494. Deutsche Medizinische Wochenschrift 1988; 113:374-380.

32 Büchler M, Friess H, Malfertheiner P, Schultheiss KH, Muhrer KH, Kraemer HP, Beger HG. Studies of pancreatic cancer utilizing monoclonal antibodies. Int J Pancreatol 1990; 7: 151-157.

33 Büchler M, Friess H, Schultheiss KH, Gebhardt Ch, Kübel R, Muhrer KH, Winkelmann M, Wagener Th, Klapdor R, Kaul M, Müller G, Schulz G, Beger HG. A randomized controlled trial of adjuvant immunotherapy (murine monoclonal antibody 494/32) in resectable pancreatic cancer. Cancer 1991; 68: 1507-1512.

34 Büchler M, Kübel R, Klapdor R, Muhrer KH, Friess H, Lorenz B, Schulz G, Bosslet K, Beger HG. Immunotherapy of pancreatic cancer with monoclonal antibody BW 494: Results from a multicentric phase I-II trial, in Cancer Therapy, Beger HG, Büchler M, Schulz G, Reisfeld R, eds., Springer, Berlin Heidelberg, 1989; pp. 32-41.

35 Friess H, Büchler M, Schulz G, Beger HG. Therapy of pancreatic carcinoma with the monoclonal antibody $\mathrm{BW}$ 494/32: first clinical results. Immunität und Infektion 1989; 17: 24-26.

36 Schulz G, Büchler M, Muhrer KH, Klapdor R, Kubel R, Harthus HP, Madry N, Bosslet K. Immunotherapy of pancreatic cancer with monoclonal antibody BW 494. Int $J$ Cancer 1988; 2: 89-94.

37 Koprowski H, Steplewski Z, Mitchel K, Herlyn M, Herlyn D, Fuhrer P. Colorectal carcinoma detected by hybridoma antibodies. Somat Cell Genet 1979; 5: 957-972.

38 Steplewski Z, Lubeck MD, Koprowski H. Human macrophages armed with murine IgG2a anti-tumor immunoglobulin destroy human cancer cells. Science 1983; 221: 865-867.

39 Gottlinger H, Funke I, Johnson JP, Gokel JM, Reithmüller G. The epithelial cell surface antigen 17-1A, a target for antibody mediated tumor therapy: its biochemical nature, tissue distribution and recognition by different monoclonal antibodies. Int $J$ Cancer 1986; 38: 47-53.

40 Sears HF, Steplewski Z, Herlyn D, Koprowski H. Effects of monoclonal antibody immunotherapy on patients with gastrointestinal adenocarcinoma. J Biol Resp Mod 1984; 3: 138-150.

41 Adams DO, Hall T, Steplewski Z, Koprowski H. Tumors undergoing regression induced by monoclonal antibodies of the $\operatorname{IgG} 2 \mathrm{a}$ isotype contain increased numbers of macrophages activated for a distinctive form of antibodycytolysis. Proc Natl Acad Sci USA 1984; 81: 3506-3510.

42 Bosslet K, Kern HF, Kanzy EJ, Steinstraesser A, Schwarz A, Luben G, Schorlemmer HU, Sedlacek HH. A monoclonal antibody with binding and inhibiting activity towards human pancreatic carcinoma cells. I: Immunohistological and immunochemical characterization of a murine monoclonal antibody selecting for well differentiated adenocarcinomas of the pancreas. Cancer Immunol Immunother 1986; 23: 185-191.

43 Kübel R, Büchler M, Baczako K, Beger HG. Immunohistochemistry in pancreatic cancer with new monoclonal antibodies. Lang Arch Chir 1987; 371: 243-252.
44 Montz R, Klapdor R, Rothe B, Heller M. Immunoscintigraphy and radioimmunotherapy in patients with pancreatic carcinoma. Nuklearmedizin 1986; 25: 239-244.

45 Kern HF, Bosslet K, Mollenhauer J, Sedlacek HH, Schorlemmer HU. Monocyte-related functions expressed in cell lines established from human pancreatic adenocarcinoma. I: Comparative analysis of endocytotic activity, lysosomal enzyme secretion, and superoxide anion production. Pancreas 1987; 2: 212-221.

46 Kern HF, Bosslet K, Sedlacek HH, Schorlemmer HU. Monocyte-related functions expressed in cell lines established from human pancreatic adenocarcinoma. II. Inhibition of stimulated activity by monoclonal antibodies reacting with surface antigens on tumor cells. Pancreas 1988; 3: 2-10.

47 Klapdor R, Lander S, Bahlo M, Montz R. Radioimmunotherapy of xenografts of human pancreatic carcinomasintravenous and intratumoral application of 1311-labeled monoclonal antibodies. Nuklearmedizin 1986; 25: 235-238.

48 Hermanek P, Scheibe O, Spiessl B, Wagner G. TNM Klassifikation maligner Tumoren, Springer, Berlin, 1987.

49 Sears HF, Herlyn D, Steplewski Z, Koprowski H. Phase II clinical trial of a murine monoclonal antibody cytotoxic for gastrointestinal adenocarcinoma. Cancer Res 1985; 45: 5910-5913.

50 Herlyn D, Koprowski H. IgG2a monoclonal antibodies inhibithuman tumor growth through interaction with effector cells. Proc Natl Acad Sci USA 1982; 79: 4761-4765.

51 Herlyn DM, Steplewski Z, Herlyn MF, Koprowski H. Inhibition of growth of colorectal carcinoma in nude mice by monoclonal antibody. Cancer Res 1980; 40: 717-721.

52 Houghton AN, Mintzer D, Cordon-Cardo C, Weltm S, Fliegel B, Vadhan S, Carswell E, Melamed MR, Oettgen HF, Old LJ. Mouse monoclonal IgG3 antibody detecting GD3 ganglioside: a phase I trial in patients with malignant melanoma. Proc Natl Acad Sci USA 1985; 82: 1242-1246.

53 Bosslet K, Döring N, Seemann G, Schulz G, Sedlacek HH. Immunological tailoring of monoclonal antibodies for immunotherapy of pancreatic carcinoma. Int J Cancer 1988; 2: 85-88.

54 Herlyn D, Wettendorff M, Schmoll E, Iliopoulos D, Schedel I, Dreikhausen U, Raab R, Ross AH, Jaksche H, Scriba M. Anti-idiotype immunization of cancer patients: modulation of the immune response. Proc Natl Acad Sci USA 1987; 84: 8055-8059.

55 Herlyn D, Ross AH, Koprowski H. Anti-idiotypic antibodies bear the internal image of a human tumor antigen. Science 1986; 232: 100-102.

56 Wettendorff M, Iliopoulos D, Tempero M, Kay D, DeFreitas E, Koprowski H, Herlyn D. Idiotypic cascades in cancer patients treated with monoclonal antibody C017-1A. Proc Natl Acad Sci USA 1989; 86: 3787-3791.

57 Herlyn D, Sears H, Iliopoulos D, Lubeck M, Douillard JY, Sindelar W, Tempero M, Mellstedt H, Maher M, Koprowski $H$. Anti-idiotypic antibodies to monoclonal antibody C017-1A. Hybridoma 1986; 5: 51-58.

58 Kennedy RC, Zhou EM, Lanford RE, Chanh TC, Bona CA. Possible role of anti-idiotypic antibodies in the induction of tumor immunity. J Clin Invest 1987; 80: 1217-1224. 
59 Bosslet K, Keweloh HC, Hermentin P, Muhrer KH, Sedlacek HH, Schulz G. Percolation and binding of monoclonal antibody BW494 to pancreatic carcinoma tissues during high dose immunotherapy and consequences for future therapy modalities. BrJ Cancer 1990; 10:37-39.

60 Goodman GE, Hellstrom I, Yelton DE, Murray JL, O'Hara S, Meaker E, Zeigler L, Palazollo P, Nicaise C, Usakewicz J. Phase I trial of chimeric (human-mouse) monoclonal antibody L6 in patients with non-small-cell lung, colon, and breast cancer. Cancer Immunol Immunother 1993; 36: 267-273.

61 Kushner BH, Cheung NK. GM-CSF enhances 3F8 monoclonal antibody-dependent cellular cytotoxicity against human melanoma and neuroblastoma. Blood 1989; 73: 1936-1941.

62 Senter PD. Activation of prodrugs by antibody-enzyme conjugates: a new approach to cancer therapy. FASEB J 1990; 4: 188-193.
63 Svensson HP, Kadow JF, Vrudhula VM, Wallace PM, Senter PD. Monoclonal antibody-beta-lactamase conjugates for the activation of a cephalosporin mustard prodrug. Bioconjugate Chem 1992; 3: 176-181.

64 Senter PD, Wallace PM, Svensson HP, Kerr DE, Hellstrom I, Hellstrom KE. Activation of prodrugs by antibody-enzyme conjugates. Adv ExpMed Biol 1991;303: 97-105.

65 Stalb L, Link KH, Mitchell MS. Immunomodulation of pancreatic cancer in vitro. Effect of monoclonal antibodies, GM-CSF and lymphokine-activated killer cells. Digestion 1992; 52: 124.

66 Riethmuller G, Schneider-GadickeE, Schlimok G, Schmiegei W, Raab R, Hoffken K, Gruber R, Pichimaier H, Hirche H, Pichimayr R. Randomised trial of monoclonal antibody for adjuvant therapy of resected Dukes' C colorectal carcinoma. Lancet 1994; 343: 1177-1183. 